\title{
Redescription of Eubothrium fragile (Rudolphi, 1802) and E. rugosum (Batsch, 1786) (Cestoda: Pseudophyllidea), parasites of fish in the Holarctic Region
}

\author{
Roman Kuchta $^{1}$, Vladimíra Hanzelová ${ }^{2}$, Andy P. Shinn ${ }^{3}$, Larisa G. Poddubnaya ${ }^{4}$ and Tomáš Scholz ${ }^{1}$ \\ ${ }^{1}$ Institute of Parasitology, Academy of Sciences of the Czech Republic and Faculty of Biological Sciences, University of South \\ Bohemia, Branišovská 31, 37005 České Budějovice, Czech Republic; \\ ${ }^{2}$ Parasitological Institute, Slovak Academy of Sciences, Hlinkova 3, 04010 Košice, Slovakia; \\ ${ }^{3}$ Institute of Aquaculture, University of Stirling, Stirling FK9 4LA, Scotland, UK; \\ ${ }^{4}$ Institute of Biology of Inland Waters, Russian Academy of Sciences, 152742 Borok, Yaroslavl Province, Russia
}

Key words: Eubothrium fragile, Eubothrium rugosum, redescription, fish cestodes, Lota lota, Alosa fallax, morphology

\begin{abstract}
Two fish cestodes, the little-known Eubothrium fragile (Rudolphi, 1802) and E. rugosum (Batsch, 1786), the type species of the genus Eubothrium Nybelin, 1922, are redescribed on the basis of new material from twaite shad, Alosa fallax (Lacépède, 1803), from England and burbot, Lota lota (Linnaeus, 1758), from Russia, respectively. The tapeworms are compared with two other species of the genus, E. crassum (Bloch, 1779) and E. salvelini (Schrank, 1790), common parasites of salmonid fish in the Holarctic. The most notable differential characters are the size and the shape of the scolex (smaller and oval in $E$. fragile), the shape of the apical disc (four or more indentations in E. crassum), the number and size of the testes (the largest and least numerous in E. rugosum), and the position and size of the vitelline follicles (almost entirely cortical in distribution in E. fragile and E. crassum versus largely medullary in E. rugosum and E. salvelini). A comparison of species has also shown the morphological similarity of the freshwater species (E. rugosum and E. salvelini) on one hand and those of marine origin, E. fragile and E. crassum, on the other, with the latter species occurring also in fresh waters. A key to the identification of the species studied is also provided.
\end{abstract}

Cestodes of the genus Eubothrium Nybelin, 1922 are common parasites of marine and freshwater fishes with a circumpolar distribution. The genus contains 10 species considered to be valid (Schmidt 1986), but most of them are insufficiently known (Andersen and Kennedy 1983). Descriptions of most species are based on an excellent, but outdated morphological study by Nybelin (1922), in which intraspecific variability was not considered. Together with the uniformity of Eubothrium tapeworms (Andersen and Kennedy 1983), the shortage of detailed morphological descriptions of individual taxa makes it difficult to identify species of Eubothrium merely on morphological grounds. The spectrum of fish definitive hosts has often been used as the most important criterion for species differentiation. This has caused many misidentifications, especially among species of Eubothrium collected from salmonid hosts, such as Pacific salmon (Oncorhynchus spp.), charr (Salvelinus alpinus) and whitefish (Coregonus spp.) (Scholz et al. 2003).

In this paper, new information relating to the morphology and morphometric measurement of a littleknown species, E. fragile, and the type species of the genus, E. rugosum, is provided to facilitate their identification and differentiation from the two most fre- quently encountered species, E. crassum and $E$. salvelini, which have recently been characterised by Hanzelová et al. (2002). In addition, the morphology of these species is compared and commented on with emphasis on the relationships among freshwater and marine species of Eubothrium.

\section{MATERIALS AND METHODS}

The present study was based on morphological and biometrical evaluation of freshly-collected specimens as well as on material deposited in museum collections. The material investigated included the following specimens:

\section{Eubothrium fragile}

(i) 15 fresh specimens collected by one of the authors (A.P.S.) from spawning twaite shad (Alosa fallax (Lacepède, 1803)) from the River Severn, England, UK, in May 2002 and in June 2003. Voucher specimens have been deposited in the helminthological collection of the Institute of Parasitology, AS CR, České Budějovice, Czech Republic (IPCAS C-398), The Natural History Museum, London, UK (BMNH No. 2005. 7.29.1-2) and the U.S. National Parasite Collection, Beltsville, USA (USNPC 96982);

(ii) specimens collected by D. Whittaker from A. fallax, Scarborough, England, UK, in November 1979 (cross-sections only) (BMNH 1979.1.12.63-65).

Address for correspondence: T. Scholz, Institute of Parasitology, Academy of Sciences of the Czech Republic, Branišovská 31 , 370 05 České Budějovice, Czech Republic. Phone: ++420 387775 403; Fax: ++420 385310 388; E-mail: tscholz@paru.cas.cz 
During the search for museum specimens of E. fragile, it was found that the type material of this cestode, originally deposited in the Natural History Museum in Berlin (NHMB), had been lost (Hartwich and Kilias 1992). In order to enable comparative studies on $E$. fragile in the future, a specimen from the type host, Alosa fallax, from the River Severn, collected by A.P. Shinn in June 2003, was designated as the neotype. The slide has been deposited in the Natural History Museum in Berlin, Germany (NHMB No. 7400), where Rudolphi's types of Taenia fragilis $(=E$. fragile) were originally stored.

\section{Eubothrium rugosum}

(i) 40 fresh specimens collected by three of the authors (L.G.P., R.K., and T.S.) from burbot, Lota lota (Linnaeus, 1758), from the Rybinsk water reservoir, Yaroslavl District, Russia, in January 2001 and 2002 and in June 2004 (IPCAS C-327, BMNH 2005.7.29.3-4, USNPC 96983, 96984);

(ii) two specimens collected by K. Andersen from L. lota in Norway (IPCAS C-327);

(iii) two specimens collected by R. Hakala and P. Rintamäki from L. lota from Kuusamon, Kitkajärvi, Finland, August 1981 (BMNH 1981.5.7.1-9);

(iv) two specimens collected by A. von Linstow from $L$. lota, from an unknown locality in Germany (NHMB 5005);

(v) one specimen collected by P.M. Muzzall (see Muzzall et al. 2003) from L. lota, Lake Huron, Michigan, USA, July 1999 (USNPC 92404);

(vi) one specimen collected by R.R. Gruley from Lake Erie, North America, in 1895 (USNPC 39800).

In addition, one immature cestode collected from an alewife Alosa pseudoharengus (Wilson, 1811) from Lake Michigan, Michigan, USA, 1990 (USNPC 83230), identified as $E$. salvelini (see Muzzall 1994), was also studied.

Specimens collected by the present authors were fixed with hot $4 \%$ formaldehyde. This fixation has been proven suitable for comparative morphological, biometrical and scanning electron microscopical (SEM) based studies on a number of fish cestode genera (see Scholz and Hanzelová 1998, de Chambrier and Vaucher 1999, Hanzelová et al. 2002). The tapeworms were then stained with Mayer's carmine, dehydrated through an ethanol series and then mounted in Canada balsam as permanent preparations. Cross and longitudinal 12 $\mu \mathrm{m}$ thick sections were prepared using a standard histological procedure of staining with haematoxylin-eosin and then mounting in Canada balsam. Several scoleces were prepared for SEM study using the methodology outlined by Scholz et al. (1998); measurements were taken as described by Hanzelová et al. (2002).

\section{RESULTS}

Eubothrium fragile (Rudolphi, 1802) Nybelin, 1922 Figs. 1A, B, F, 2A, C, 3C, D, F, Table 1

Synonyms (according to Protasova 1977): Taenia fragilis Rudolphi, 1802; Bothriocephalus fragilis (Rudolphi, 1802) Rudolphi, 1810; Ligula simplissima Fuhlrott, 1847; Dibothrium fragile (Rudolphi, 1802) Diesing, 1851; Bothriotaenia fragilis (Rudolphi, 1802) Blanchard, 1894; Abothrium fragile (Rudolphi, 1802) Lühe, 1899.
Description (based on 15 specimens from Alosa fallax, River Severn, England, UK; measurements are provided in Table 1): Total length up to $20 \mathrm{~cm}$. Proglottids wider than long. Secondary segmentation present. Dorsal and ventral surfaces of strobila with longitudinal grooves.

Scolex small, up to $550 \mu \mathrm{m}$ long, almost spherical, slightly flattened dorsoventrally (Figs. 1A, B, 3C, D). Apical disc small, inconspicuous, bilobed, bilaterally symmetrical, with two weakly developed grooves on dorsal and ventral surfaces (Figs. 1A, 3F). Bothria oval, shallow, with massive walls (Figs. 1A, 3C, F). Neck short and wide (Fig. 1A, B).

Testes medullary, spherical, small and numerous, forming two fields connected in postovarian space by a single row of testes, absent in ovarian and cirrus-sac space (Figs. 1F, 2A). Cirrus-sac relatively small, oval to elongate, reaching beyond poral nerve cord (Fig. 1F), opening with vagina into shallow genital atrium (Fig. $1 F)$. Cirrus inconspicuous. Vas deferens (sperm duct) forming several loops near median line of proglottids, directed towards ovary (Fig. 1F). Main lateral longitudinal nerve cords prominent and easy to see (Figs. 1F, 2A).

Genital atrium lateral, alternating irregularly, usually pre-equatorial to equatorial (Fig. 1F). Ovary median, bean- or kidney-shaped (also in cross-sections), slightly lobed, with larger aporal lobe (Figs. 1F, 2A). In mature proglottids, ovary more anterior than in gravid proglottids. Vagina tubular, crossing ovarian isthmus dorsally, then bends laterally to open into genital atrium, anterior to cirrus-sac; distal (terminal) part of vagina enlarged near genital atrium (Fig. 1F). Vitelline follicles numerous, oval, very small, forming single band surrounding reproductive organs, present along median line of body; follicles largely cortical, with only few entering among inner longitudinal muscle bundles (Figs. 1F, 2A, C).

Uterine duct curved, filled with eggs in gravid proglottids. Uterine sac anterior, elongate, thick-walled, extending anteriorly from mid-ventral uterine pore to anterior margin of proglottid (Fig. 1F). In first gravid proglottids, eggs fill uterine duct only. In more developed gravid proglottids, uterine duct and uterine sac filled with eggs, occupy most space anterior to ovary; uterine sac short and wide. Eggs unoperculate, embryonated when laid.

T y p e h o s t: Alosa fallax (Lacépède, 1803) (Clupeiformes: Clupeidae).

O t h e r h o s t : Alosa alosa (Linnaeus, 1758) (Clupeiformes: Clupeidae) (see Remarks).

Ge ographical distribution: Europe-Baltic Sea (Germany, Sweden), Bristol Channel (England), North Sea (England).

R e f e r e n c e s : Nybelin (1922), Fischer (1955), Kennedy (1978b, 1981) 

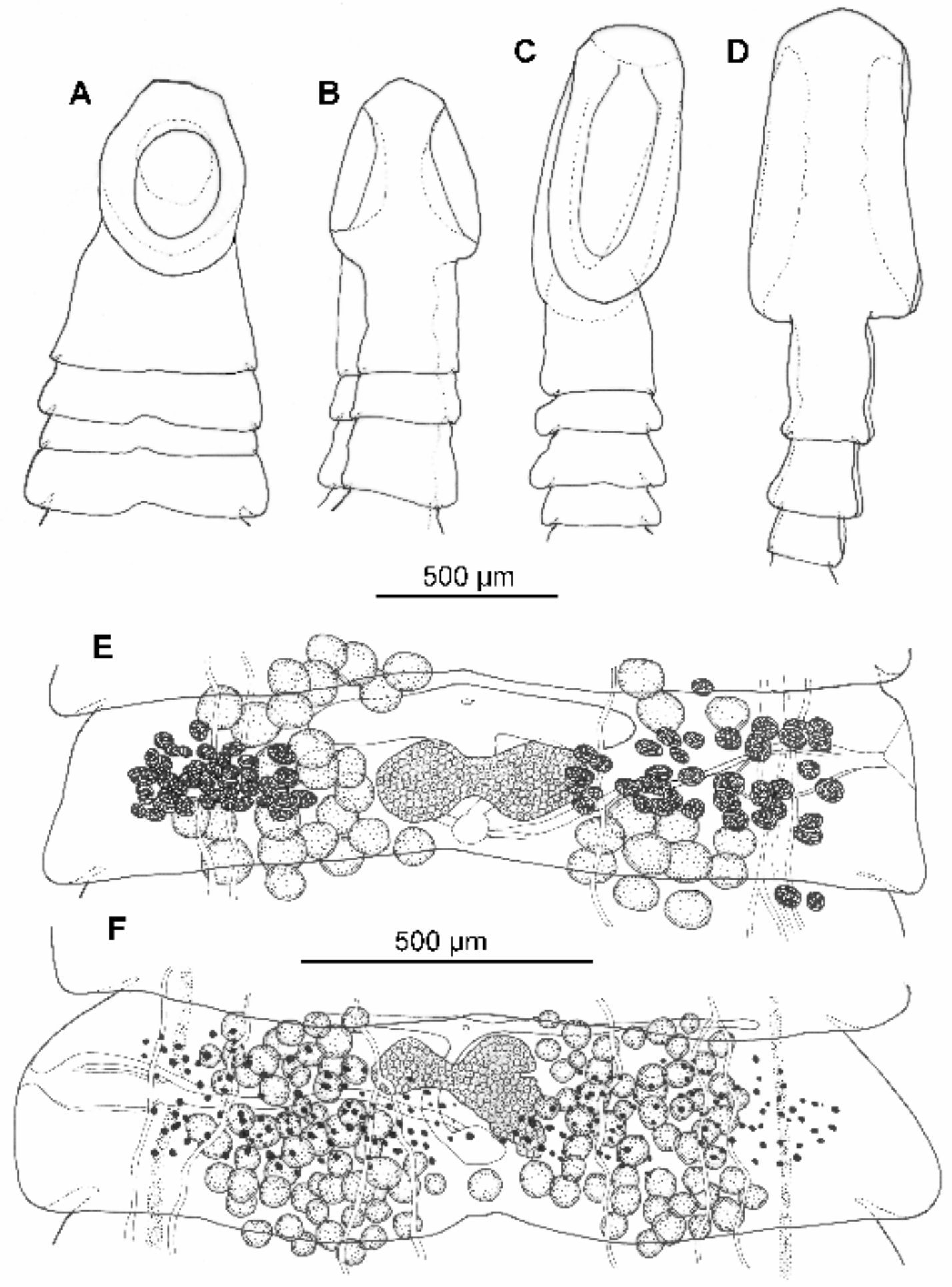

Fig. 1. A, B, F - Eubothrium fragile from Alosa fallax; C-E - Eubothrium rugosum from Lota lota. A, C - scolex dorsoventrally; B, D - scolex laterally; E, F - mature proglottid.

Remarks. The species was described by Rudolphi (1802) as Taenia fragilis and then transferred to several genera by different authors (see list of synonyms), before finally being placed within the genus Eubothrium by Nybelin (1922). This author provided a fairly detailed morphological description of $E$. fragile based on specimens from Alosa fallax from Sweden, but many crucial morphological characters and measurements 
were omitted. Kennedy (1981) provided data on the biology and ecology of the species. Andersen and Kennedy (1983) presented a brief account of the species with scanning electron micrographs of the scolex, but only a few new morphological data were provided. The present study provides more details of the morphology and measurements of $E$. fragile, including the first report of the measurements of several structures and organs, including the size of the eggs (Table 1).

Eubothrium fragile is a specific parasite of shad (Alosa spp.), but previous records from hosts other than twaite shad ( $A$. fallax) should be revised. Kennedy (1981) questioned the findings of E. fragile in A. alosa reported by Joyeux and Baer (1936). Muzzall (1994) found cestodes identified as "Eubothrium salvelini" in Alosa pseudoharengus from Lake Michigan in Canada. However, based on the material examined in the current study (one immature specimen - USNPC 83230), it cannot be ruled out that this tapeworm may be E. fragile.

Recent records of $E$. fragile originate only from the western and northern parts of Europe (Baltic and North Seas, Bristol Channel). It seems to be absent in Russia (in both its European and Asian parts) and from North America (Protasova 1977, Margolis and Arthur 1979, Dubinina 1987, Hoffman 1999).

Eubothrium clupeonellae Dogiel et Bychowsky, 1938 was described from another clupeiform fish, Clupeonella delicatula $[=C$. cultriventris (Nordmann, 1840)] from the Caspian Sea. Andersen and Kennedy (1983) considered this species to be a possible synonym of $E$. fragile, considering the similarity of their fish hosts. The original description of E. clupeonellae is very brief, superficial and is supplemented with very schematic illustrations (Dogiel and Bychowsky 1938). Nevertheless, it clearly demonstrates that this species differs from $E$. fragile by possessing a markedly different shaped and sized scolex. In its general morphology, $E$. clupeonellae resembles E. acipenserinum Cholodkovsky, 1918, described from sturgeon in the Caspian Sea, rather than E. fragile. Protasova (1977) considered E. clupeonellae to be a species inquirenda. Like E. crassum, E. fragile is most probably of marine origin (Andersen and Kennedy 1983), but it can survive residence in freshwater for short periods during spawning of the host (Kennedy 1981).

Eubothrium rugosum (Batsch, 1786) Nybelin, 1922 Figs. 1C-E, 2B, D, 3A, B, E, Table 1

Synonyms (according to Protasova 1977): Taenia rugosa Batsch, 1786; Bothriocephalus rugosus (Batsch, 1786) Rudolphi, 1810; B. infundibuliformis Zschokke, 1884; Dibothrium rugosum (Batsch, 1786) Diesing, 1871; Abothrium rugosum (Batsch, 1786) Lönnberg, 1891; A. gadi Spengel, 1907 nec van Beneden, 1871; Rhytis conoceps Zeder, 1803; Bothriotaenia rugosa (Batsch, 1786) Blanchard, 1894.
Description (based on 17 specimens from Lota lota from the Rybinsk water reservoir, Russia; measurements given in Table 1): Adult tapeworms up to $50 \mathrm{~cm}$ long, with markedly craspedote proglottids, wider than long (Fig. 1E). Secondary segmentation present.

Scolex of medium size, elongate; apical disc prominent, bilobed, convex, with only shallow indentations on dorsal and ventral surfaces above bothria (Figs. 1C, D, 3A, B, E). Bothria elongate, shallow, with massive walls (Figs. 1C, 3A, E). Neck short, narrow (Fig. 1C, D).

Testes medullary, spherical, large, not numerous, forming two fields connected in post-ovarian space by single row of testes, absent around ovary and cirrus-sac (Fig. 1E). Cirrus-sac relatively small, oval to elongate, not reaching poral nerve cord, opens with vagina into shallow genital atrium (Figs. 1E, 2B). Vas deferens (sperm duct) weakly coiled at its proximal end (Fig. 1E). Main lateral longitudinal nerve cords difficult to see (Fig. 2B).

Genital atrium lateral, irregularly alternating, preequatorial to slightly post-equatorial (Fig. 1E). Ovary bilobed or bean-shaped, also in cross-sections (Fig. 1E, 2B), slightly asymmetrical, with larger aporal lobe, slightly lobulate laterally, median in position. Width of ovary represents about one-quarter of proglottid width. Vagina tubular, crosses ovarian isthmus dorsally, then bends laterally to open anterior to cirrus-sac into genital atrium; distal (lateral) part of vagina enlarged near genital atrium. Vitelline follicles medullary, with some follicles entering between inner muscles bundles (Fig. 2B, D); follicles not numerous, relatively large, irregular in shape, grouped together, forming two well-separated lateral fields, absent medially (Fig. 2B).

Uterine duct curved, filled with eggs in gravid proglottids. Uterine sac anterior, elongate, thick-walled, extending anteriorly from mid-ventral uterine pore to anterior margin of proglottids (Fig. 1E). In first gravid proglottids, eggs filling uterine duct only; in more developed gravid proglottids, uterine duct and uterine sac filled with eggs and occupying most space anterior to ovary. Eggs unoperculate, embryonated, relatively large (Table 1).

T y p e h o s t : Lota lota (Linnaeus, 1758) (Gadiformes: Gadidae).

G e o graphic a 1 distributio n : Europe (Finland, Germany, Norway, Poland, Sweden, Russia - St Petersburg Region, Karelia, Volga River basin), Asia (Russia - basins of Pechora, Ob, Yenisei and Lena Rivers), North America (Canada, USA).

R e f e r e n c e s : Cooper (1918 - as Abothrium crassum), Nybelin (1922), Zandt (1924), Wardle (1932, 1933), Kuitunen-Ekbaum (1933), Rawson (1957), Bangham and Adams (1954), Engelbrecht (1956 - as Bothriocephalus claviceps), Kozicka (1959), Dechtiar (1972), Kuperman (1974), Mudry and Anderson (1977), Margolis and Arthur (1979), Leong and Holmes (1981), Andersen and Kennedy 

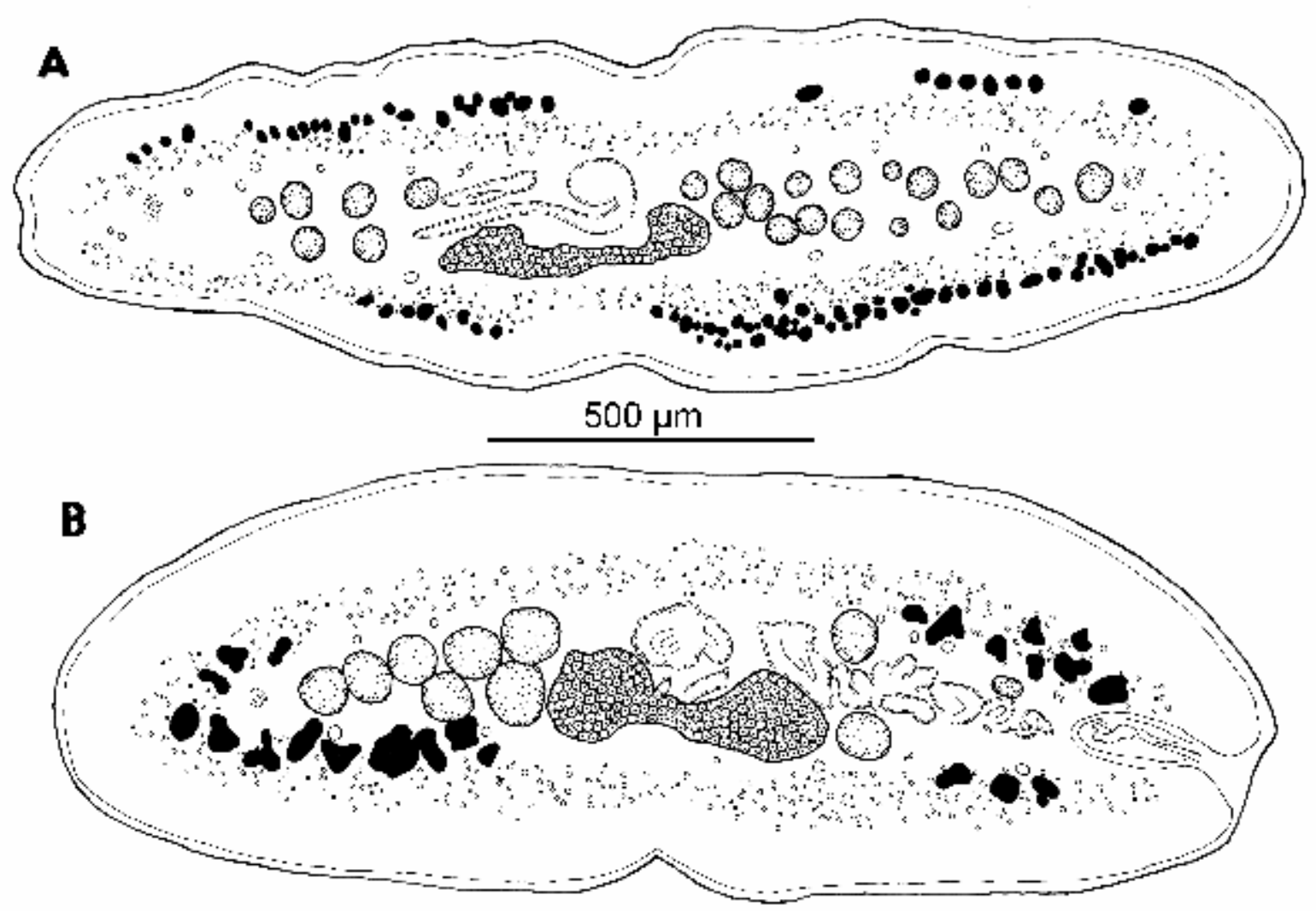

C

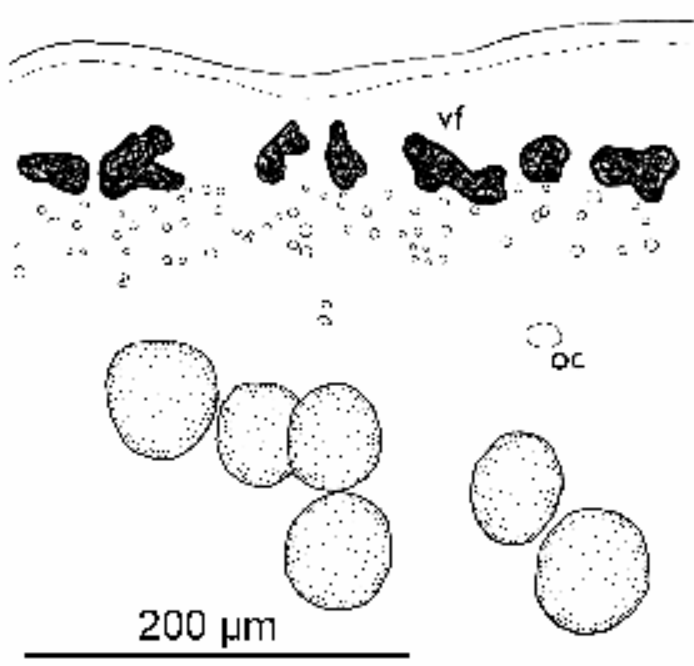

D
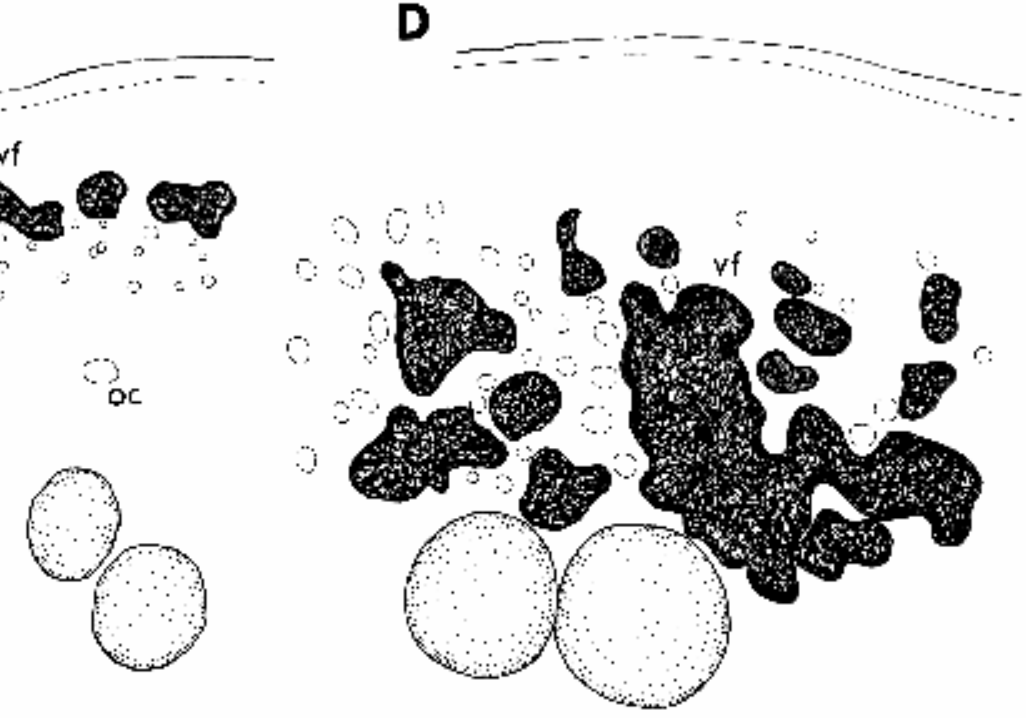

Fig. 2. A, C - Eubothrium fragile from Alosa fallax; B, D - Eubothrium rugosum from Lota lota. A, B - cross-sections at level of the ovary (slightly oblique); C, D - detail of vitelline follicles in cross-sections. oc - osmoregulary canals; vf - vitelline follicles.

(1983), McAllister and Mudry (1983), Pugachev (1984), Turovskij (1985), Wierzbicka and Sobecka (1985), Dubinina (1987), Dechtiar and Lawrie (1988), Dechtiar et al. (1988), Dorovskikh (2000), Muzzall et al. (2003), Poddubnaya (2003).
Remarks. The species was first reported by Goeze (1782) under the name "Der runzlichter Fischbandwurm", but its first description was provided by Batsch (1786) who named it Taenia rugosa. Thereafter, this species was transferred to several genera, namely 
Bothriocephalus, Dibothrium and Abothrium (see list of synonyms). Nybelin (1922), who established the genus Eubothrium, designated Taenia rugosa as its type species.

On the basis of the scolex morphology, Wardle (1932) and Kuitunen-Ekbaum (1933) proposed two forms (varieties) of E. rugosum, E. rugosum var. conformatus with a typical scolex and E. rugosum var. deformatus with the scolex lacking bothria and an apical disc. However, certain authors did not accept these forms, because they differed only in the shape of the scolex (Wardle and McLeod 1952, Schmidt 1986). Andersen and Kennedy (1983), however, did recognise both forms and distinguished them not only by the shape of the scolex but also by differences in the shape and size of the cirrus-sac and the organisation of the inner muscle bundles.

The present data on the morphology and measurements of E. rugosum correspond more or less with those reported by previous authors, in particular by Nybelin (1922) and Protasova (1977). The most marked differences, however, are in the diameter of the testes and in the length and width of the eggs (Table 1; Nybelin 1922, Protasova 1977). Several characters, including the number of testes, the length/width ratio and relative length of the cirrus-sac, are provided for the first time (Table 1).

Eubothrium rugosum is a relatively common, specific parasite of Lota lota. It occurs in northern Europe, Asia and North America. It is probably of freshwater origin, as is E. salvelini that parasitizes charr (Salvelinus spp.) and Pacific salmon (Oncorhynchus spp.) in the Holarctic region (Andersen and Kennedy 1983, Scholz et al. 2003).

Planktonic copepods, such as Cyclops strenuus Fischer, 1851, C. vicinus Uljanin, 1875, Microcyclops bicolor (Sars, 1863) and M. varicans (Sars, 1863), serve as intermediate hosts, whereas the ruffe, Gymnocephalus cernuus (Linnaeus, 1758), is a paratenic host of $E$. rugosum (Kuperman 1974).

\section{DISCUSSION}

Eubothrium is of particular interest for parasitologists and fishery biologists in that some species are marine, others freshwater and one species, E. crassum, inhabits both water habitats (Kennedy 1978a, b). Species identification has presented difficulties due to their general morphological uniformity and a limited number of species-specific characters (Nybelin 1922, Kennedy 1978a, b, Andersen and Kennedy 1983). Some taxa occurring in a wide spectrum of fish hosts, such as E. crassum, exhibit a high degree of intraspecific variability, especially among populations from different hosts (Andersen and Kennedy 1983). The other difficulty stems from the low quality of most specimens of Eubothrium that have been deposited in collections (Hanzelová et al. 2002, Scholz et al. 2003).
Nybelin (1922) provided an excellent description of Eubothrium tapeworms and differentiated individual species on the basis of the size and shape of the scolex, the size of the cirrus-sac, the confluence of testicular fields between adjacent proglottids, the position of the vitelline follicles in relation to the longitudinal muscle bundles, and the spectrum of fish hosts used. However, Kennedy (1978a, b) and Andersen and Kennedy (1983) questioned the suitability of certain characters for identification of species, especially the shape and size of the scolex.

The present data support some of Nybelin's (1922) conclusions and the results of recent studies, based on comparable material of four species of Eubothrium (Hanzelová et al. 2002, 2005, Scholz et al. 2003, Šnábel et al. 2004, Kuchta et al. in press). The measurements of the scolex and its shape may help to distinguish individual Eubothrium species. This seems to be valid even for the morphologically variable species such as E. crassum. Specimens of this species from marine hosts are markedly larger than those from freshwater hosts (Andersen and Kennedy 1983). Morphological variability, however, is not reflected in the genetic structure of $E$. crassum (isoenzyme patterns and sequences of the ITS rRNA genes) of freshwater and marine populations (Král'ová et al. 2000, 2001, Král'ová-Hromadová et al. 2003, Šnábel et al. 2004).

Andersen and Kennedy (1983) considered strobilar characters to be unsuitable for species differentiation due to their variability among different host and geographic populations. Overlaps in the measurements of many strobilar characters between Eubothrium species have also been demonstrated by the present authors and by Hanzelová et al. (2002, 2005). Nevertheless, some characters, such as the size, shape and position of the vitelline follicles, and the number and size of the testes, appear to be rather stable and suitable for species differentiation (Table 1).

On the contrary, the size of the cirrus-sac, previously used as a differential character (Nybelin 1922, Andersen and Kennedy 1983), is not suitable for species identification because its values overlap between species (Hanzelová et al. 2002, this study - Table 1).

Based on the position of the vitelline follicles in relation to the inner longitudinal musculature, Eubothrium species can be divided into three groups. Marine species (E. crassum, E. fragile, E. parvum Nybelin, 1922, E. vittevitellatus Mamaev, 1968) have most of their vitelline follicles distributed cortically, whereas those species living primarily in freshwater hosts (E. salvelini, E. rugosum, E. tulipai Ching et Andersen, 1983) have follicles in the medulla (Nybelin 1922, Kennedy 1978a, b, Andersen and Kennedy 1983, Ching and Andersen 1983, the present study). Eubothrium acipenserinum, specific to sturgeon in the Caspian Sea, represents an intermediate form with paramuscular vitellaria, i.e. vitelline follicles between the muscle bundles. However, 

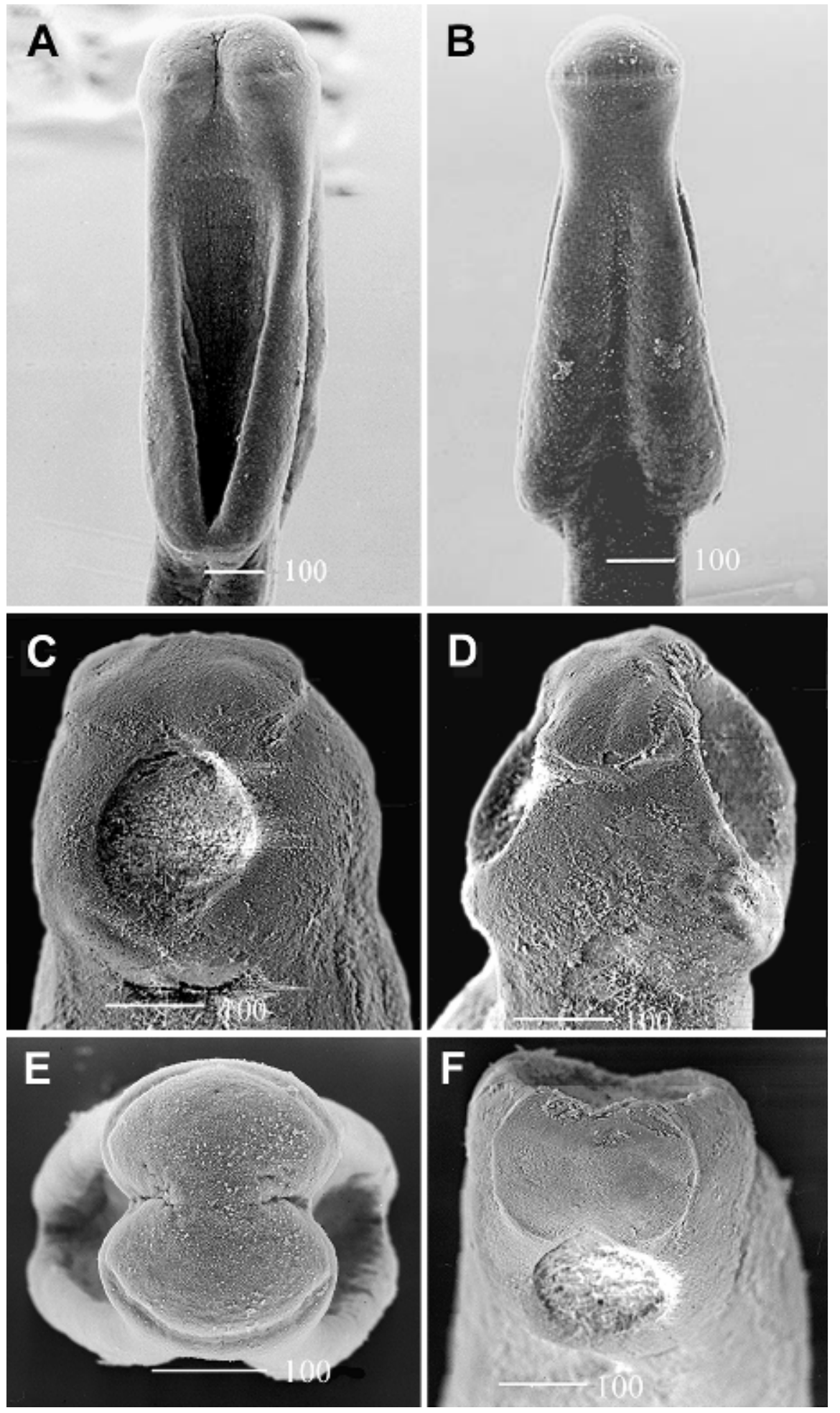

Fig. 3. A, B, E - Eubothrium rugosum from Lota lota; C, D, F - Eubothrium fragile from Alosa fallax. A, C - scolex dorsoventrally; B, D - scolex laterally; E, F - scolex apically.

its description was incomplete and the actual position of the follicles should be confirmed from new material. Eubothrium arcticum Nybelin, 1922, although apparently a marine species (type host pale eelpout Lycodes pallidus Collett, 1879 [Perciformes: Zoarcidae]), pos- sesses medullary situated vitelline follicles as seen in freshwater species (Andersen and Kennedy 1983).

Considering the difficulties that have been encountered in identifying various Eubothrium cestodes collected from various fish hosts in Europe, a simple key is 
Table 1. Measurements (in micrometres) of Eubothrium fragile from Alosa fallax, England and E. rugosum from Lota lota, Russia. Measurements are expressed as range (left column) and mean \pm standard deviation (SD) with the number of measurements in parentheses.

\begin{tabular}{|l|c|c|c|c|}
\hline \multicolumn{1}{|c|}{ Character / species } & \multicolumn{2}{|c|}{ Eubothrium fragile } & \multicolumn{2}{c|}{ Eubothrium rugosum } \\
\hline Length of scolex & $381-660$ & $474 \pm 49(15)$ & $720-1120$ & $902 \pm 98(23)$ \\
Width of scolex (dorsoventral) & $348-610$ & $420 \pm 28(15)$ & $264-790$ & $461 \pm 119(23)$ \\
Width of scolex (lateral) & $400-464$ & $432 \pm 32(3)$ & $296-680$ & $458 \pm 98(23)$ \\
Width of apical disc (dorsoventral) & $194-352$ & $233 \pm 28(15)$ & $200-472$ & $319 \pm 58(23)$ \\
Width of apical disc (lateral) & $240-304$ & $277 \pm 33(3)$ & $272-464$ & $354 \pm 53(23)$ \\
Length of bothria & $208-400$ & $317 \pm 58(15)$ & $560-840$ & $648 \pm 88(23)$ \\
Width of bothria & $208-368$ & $272 \pm 43(15)$ & $160-352$ & $220 \pm 44(23)$ \\
Length of neck & $160-496$ & $411 \pm 80(15)$ & $224-400$ & $297 \pm 52(23)$ \\
Width of neck & $297-660$ & $406 \pm 58(12)$ & $152-464$ & $279 \pm 73(23)$ \\
Length of proglottid & $224-346$ & $286 \pm 41(10)$ & $278-607$ & $367 \pm 82(24)$ \\
Width of proglottid (mm) & $1501-2621$ & $2109 \pm 355(10)$ & $1263-2403$ & $1743 \pm 286(24)$ \\
Ratio of proglottid (length/width) & $1: 0.05-0.21$ & $(11)$ & $1: 0.12-0.33$ & $(11)$ \\
Width of nerve trunk & $30-45$ & $(10)$ & $23-39$ & $(10)$ \\
Number of testes & $84-111$ & $98 \pm 10(9)$ & $56-81$ & $68 \pm 9(6)$ \\
Diameter of testes & $42-70$ & $55 \pm 8(10)$ & $55-85$ & $69 \pm 7(24)$ \\
Length of cirrus-sac & $167-239$ & $212 \pm 22(10)$ & $175-225$ & $196 \pm 13(19)$ \\
Width of cirrus-sac & $65-95$ & $83 \pm 10(10)$ & $71-90$ & $83 \pm 5(19)$ \\
Ratio of cirrus-sac (length/width) & $1: 2.25-2.90$ & $(11)$ & $1: 2.02-2.87$ & $(11)$ \\
Relative length of cirrus-sac* & $14-21 \%$ & $(10)$ & $16-20 \%$ & $(10)$ \\
Genital pore position & $31-51 \%$ & $(10)$ & $32-57 \%$ & $(10)$ \\
Width of vagina & $21-30$ & $24 \pm 3$ & $21-26$ & $23 \pm 2(10)$ \\
Area of ovary ( $\left.\mu m^{2}\right)^{* *}$ & $27-76$ & $51 \pm 16(10)$ & $16-70$ & $44 \pm 16(24)$ \\
Diameter of vitelline follicles & $18-40$ & $25 \pm 6(10)$ & $22-53$ & $38 \pm 8(24)$ \\
Length of eggs & $43-55$ & $46 \pm 9(4)$ & $56-81$ & $68 \pm 9(6)$ \\
Width of eggs & $25-32$ & $28 \pm 3(4)$ & $40-57$ & $47 \pm 4(22)$ \\
\hline
\end{tabular}

*Ratio of cirrus-sac length to proglottid width (in \%).**Area $=$ length $\times$ width.

provided for the four species of the genus that have been recently redescribed on the basis of morphological, biometrical and genetic evaluations of new material and museum specimens.

\section{Key to the identification}

1 (2) Scolex almost spherical, small, up to $650 \mu \mathrm{m}$ long, with short and wide neck; vitelline follicles largely cortical. Parasites of shad (Alosa spp.) E. fragile

2 (1) Scolex elongate, mostly longer than $650 \mu \mathrm{m}$...... 3

3 (4) Apical disc with at least four grooves (indentations), one on dorsal and one on ventral surface, and two on lateral surfaces; scolex large (800 $2000 \mu \mathrm{m}$ long); neck long and wide; vitelline follicles small, mostly cortical. Parasite of Atlantic salmon and trout (Salmo spp.), rarely in other salmonids (Coregonus, Hucho, Oncorhynchus)

E. crassum

4 (3) Apical disc with only two lobes (one on dorsal and one on ventral surface); scolex of medium size (length less than $1200 \mu \mathrm{m}$ ); neck narrow; vitelline follicles large, mostly medullary
5 (6) Vitelline follicles well separated from each other. Parasite of charr (Salvelinus), rarely of Pacific salmon (Oncorhynchus) and other salmonids (Coregonus)

E. salvelini

6 (5) Vitelline follicles forming large clusters. Parasite of burbot (Lota lota)

E. rugosum

Acknowledgements. The authors are grateful to Prof. C.R. Kennedy for his help in obtaining material of $E$. fragile and to Martina Borovková for providing technical assistance. The stays of T.S. and R.K. at the Institute of Aquaculture, University of Stirling, Scotland were supported by the Access to Research Infrastructure Action of the Improving Human Potential Programme of the European Community (contract HPRI-CT-2001-00180). The authors are indebted to Prof. Christina Sommerville, head of the Parasitology Laboratory, and to Dr. Rod Wootten, Deputy Director, Institute of Aquaculture, for their support and for placing the Institute's facilities at their disposal. This study was partially supported by the Grant Agency of the Czech Republic (projects Nos. 524/03/H133 and 524/04/0342), the Institute of Parasitology AS CR research project (Z60220518), the research project of the Faculty of Biological Sciences USB (MSM 6007665801), and the Slovak Grant Agency VEGA (project No. 2/4177/04). 


\section{REFERENCES}

ANDERSEN K.I., KENNEDY C.R. 1983: Systematics of the genus Eubothrium Nybelin (Cestoda, Pseudophyllidea), with partial re-description of the species. Zool. Scr. 12: 95-105.

BANGHAM R.V., ADAMS J.R. 1954: A survey of the parasites of freshwater fishes from the mainland of British Columbia. J. Fish. Res. 11: 673-708.

BATSCH A.J.G. 1786: Naturgeschichte der Bandwurmgattung ueberhaupt und ihrer Arten insbesondere, nach den neuern Beobachtungen in einem systematischen Auszuge. Halle, 298 pp.

CHING H.L., ANDERSEN K. 1983: Description of Eubothrium tulipai sp. n. (Pseudophyllidea: Amphicotylidae) from northern squawfish in British Columbia. Can. J. Zool. 61: 981986.

de CHAMBRIER A., VAUCHER C. 1999: Proteocephalidae et Monticelliidae (Eucestoda: Proteocephalidea) parasites de poissons d'eau douce au Paraguay, avec descriptions d'un genre nouveau et de dix espèces nouvelles. Rev. Suisse Zool. 106: $165-240$.

COOPER A.R. 1918: North American pseudophyllidean cestodes from fishes. Ill. Biol. Monogr. 4, 243 pp.

DECHTIAR A.O. 1972: Parasites of fish from Lake of the Woods, Ontario. J. Fish. Res. Board Can. 29: 275-283.

DECHTIAR A.O., COLLINS J.J., RECKHAM J.A. 1988: Survey of the parasite fauna of Lake Huron fishes, 1961 to 1971. Great Lakes Fisheries Commission, Technical Report 51: 19-48.

DECHTIAR A.O., LAWRIE A.H. 1988: Survey of the parasite fauna of Lake Superior fishes, 1969 to 1975. Great Lakes Fisheries Commission, Technical Report 51: 1-18.

DOGIEL V.A., BYCHOWSKY B.E. 1938: [Parasites of the Caspian fishes.] Trudy kompleksnogo izucheniya Kaspiiskogo morya 7: 1-179. (In Russian.)

DOROVSKIKH G.N. 2000: Results of the study of fishes parasites in river basins of the north-east of the European part of Russia. Cestoda. Parazitologiya 34: 441-446. (In Russian.)

DUBININA M.N. 1987: [Class Cestoda Rudolphi, 1808.] In: O.N. Bauer (Ed.), [Key to the Parasites of Freshwater Fishes of the USSR]. Nauka, Moscow, pp. 5-76. (In Russian.)

ENGELBRECHT H. 1956: Die Helminthen der Nutzfische des Greifswalder Boddens und Kleinen Haffs. (Ein Beitrag zur Brackwasserökologie). $\mathrm{PhD}$ thesis, University of Greifswald, 113 pp.

FISCHER E. 1955: Die parasitischen Würmer der wirtschaftlich wichtigsten Ostseefische. PhD thesis, Humboldt University Berlin, $136 \mathrm{pp}$.

GOEZE J.A.E. 1782: Versuch einer Naturgeschichte der Cestoden. Zool. Jahrb. Anat. 42: 213-228.

HANZELOVÁ V., KUCHTA R., SCHOLZ T., SHINN A.P. 2005: Morphometric analysis of four species of $E$ bothrium (Cestoda: Pseudophyllidea) parasites of salmonid fish: an interspecific and intraspecific comparison. Parasitol. Int. 54: 207-214.

HANZELOVÁ V., SCHOLZ T., GERDEAUX D., KUCHTA R. 2002: A comparative study of Eubothrium crassum (Bloch, 1779) and E. salvelini (Schrank, 1790) (Cestoda:
Pseudophyllidea), parasites of salmonid fishes in Alpine lakes. Environ. Biol. Fish 64: 245-256.

HARTWICH G., KILIAS I. 1992: Die Typen der Cercomeromorphae (Plathelminthes) des Zoologischen Museum in Berlin. Mitt. Zool. Mus. Berl. 68: 209-248.

HOFFMAN G.L. 1999: Parasites of North American Freshwater Fishes. Second Edition. Comstock Publishing Associates, Cornell University Press, Ithaca and London, $486 \mathrm{pp}$.

JOYEUX C., BAER J.G. 1936: Cestodes. Faune de France. Volume 30. Masson, Paris, $613 \mathrm{pp}$.

KENNEDY C.R. 1978a: Studies on the biology of Eubothrium salvelini and Eubothrium crassum in resident and migratory Salvelinus alpinus and Salmo trutta and in S. salar in North Norway and the islands of Spitsbergen and Jan Mayen. J. Fish Biol. 12: 147-162.

KENNEDY C.R. 1978b: The biology, specificity and habitat of the species of Eubothrium (Cestoda: Pseudophyllidea), with reference to their use as biological tags: a review. J. Fish Biol. 12: 393-410.

KENNEDY C.R. 1981: The occurrence of Eubothrium fragile (Cestoda: Pseudophyllidea) in twaite shad, Alosa fallax (Lacépède) in the River Severn. J. Fish Biol. 19: 171-177.

KOZICKA J. 1959: Parasites of fishes of Drużno Lake. Acta Parasitol. Polon. 7: 1-72.

KRÁLOOVÁ I., HANZELOVÁ V., SCHOLZ T., GERDEAUX D., ŠPAKULOVÁ M. 2001: A comparison of the internal transcribed spacer of the ribosomal DNA for Eubothrium crassum and Eubothrium salvelini (Cestoda: Pseudophyllidea), parasites of salmonid fish. Int. J. Parasitol. 31: 93-96.

KRÁLOOVÁ I., ŠNÁBEL V., SCHOLZ T., GERDEAUX D., HANZELOVÁ V. 2000: Molecular discrimination of fish tapeworms Eubothrium crassum and E. salvelini (Cestoda: Pseudophyllidea). Abstracts of VIII EMOP, Poznan, Poland. Acta Parasitol. 45: 157.

KRÁLOOVÁ-HROMADOVÁ I., SCHOLZ T., SHINN A.P., CUNNINGHAM C.O., WOOTTEN R., HANZELOVÁ V., SOMMERVILLE C. 2003: A molecular study of Eubothrium rugosum (Batsch, 1786) (Cestoda: Pseudophyllidea) using ITS rDNA sequences, with notes on the distribution and intraspecific sequence variation of Eubothrium crassum (Bloch, 1779). Parasitol. Res. 89: 473-479.

KUCHTA R., SHINN A.P., HANZELOVÁ V., SCHOLZ T. 2005: A comparative study of the egg morphology of four species of Eubothrium (Cestoda: Pseudophyllidea) with comments on their subsequent development. Invertebr. Biol. (In press.)

KUITUNEN-EKBAUM E. 1933: A study of the cestode genus Eubothrium of Nybelin in Canadian fishes. Contrib. Can. Biol. Fish., New Series 8: 89-98.

KUPERMAN B.I. 1974: [Life cycle of Eubothrium rugosum (Cestoda: Pseudophyllidea)]. IV Vsesoyuznoe soveshchanie po boleznyam i parazitam ryb, 3-5 April 1974 (Tezisy dokladov), VNIIPRCH, Moscow, pp. 138-142. (In Russian.) 
LEONG T.S., HOLMES J.C. 1981: Communities of metazoan parasites in open water fishes of Cold Lake, Alberta. J. Fish Biol. 18: 693-713.

MARGOLIS L., ARTHUR J.R. 1979: Synopsis of the parasites of fishes of Canada. Bull. Fish. Res. Board Can. 199: $1-269$.

McALLISTER D.J., MUDRY D.R. 1983: Diseases and Parasites of Alberta Fishes and Potential Consequences of Their Interbasin Transfer. Alberta Environmental Research Trust, Calgary, Canada, $80 \mathrm{pp}$.

MUDRY D.R., ANDERSON R.S. 1977: Helminth and arthropod parasites of fishes in the mountain national park of Canada. J. Fish Biol. 11: 21-33.

MUZZALL P.M. 1994: Parasites of alewives, Alosa pseudoharengus, from the Great Lakes. J. Helminthol. Soc. Wash. 61: 67-62.

MUZZALL P.M., GILLILLAND M.G., BOWEN C.A., COADY N.R., PEEBLES C.R. 2003: Parasites of burbot, Lota lota, from Lake Huron, Michigan, USA, with a checklist of the North American parasites of burbot. Comp. Parasitol. 70: 182-195.

NYBELIN O. 1922: Anatomisch-systematische Studien über Pseudophyllideen. Göteborgs kungl. Vetenskaps-och Vitterhets-Samhälles Handlingar XXVI, Med bihang 41: 1-128.

PODDUBNAYA L.G. 2003: Structure of reproductive system of the amphicotylide cestode Eubothrium rugosum (Cestoda, Pseudophyllidea). J. Evol. Biochem. Physiol. 39: 345-355.

PROTASOVA E.N. 1977: Cestodes of fish - Bothriocephalata. Principles of Cestodology. Volume VII. Nauka, Moscow, 298 pp. (In Russian.)

PUGACHEV O.N. 1984: Parasites of freshwater fishes of North-East Asia. Zoological Institute AN SSSR, Leningrad, 156 pp. (In Russian.)

RAWSON D. 1957: The anatomy of Eubothrium crassum (Bloch) from the pyloric caeca and small intestine of Salmo trutta L. J. Helminthol. 31: 103-120.
RUDOLPHI C.A. 1802: Fortsetzung der Beobachtungen ueber die Eingeweidewürmer. Arch. Zool. Zootom. 3: 61-125.

SCHMIDT G.D. 1986: CRC Handbook of Tapeworm Identification. CRC Press, Boca Raton, Florida, USA, 675 pp.

SCHOLZ T., HANZELOVÁ V. 1998: Tapeworms of the genus Proteocephalus Weinland, 1858 (Cestoda: Proteocephalidae), parasites of fishes in Europe. Studie AV ČR, 2/98, Academia, Prague, 118 pp.

SCHOLZ T., DRÁBEK R., HANZELOVÁ V. 1998. Scolex morphology of Proteocephalus tapeworms (Cestoda: Proteocephalidae), parasites of freshwater fish in the Palaearctic Region. Folia Parasitol. 45: 27-43.

SCHOLZ T., KUCHTA R., SHINN A.P., ŠNÁBEL V., HANZELOVÁ V. 2003: Host specificity and geographical distribution of Eubothrium tapeworms (Cestoda: Pseudophyllidea) in European salmonid fish. J. Helminthol. 77: 255262.

ŠNÁBEL V., HANZELOVÁ V., SCHOLZ T., GERDEAUX T., CABARET J. 2004: Allozyme analysis of genetic variation and polymorphism in Eubothrium salvelini and E. crassum (Cestoda: Pseudophyllidea) from alpine lakes. Parasitol. Res. 93: 290-295.

TUROVSKIJ A. 1985: Parasitofauna of fish in the southern Gulf of Finland. Finnish Fish. Res. 6: 106-111.

WARDLE R.A. 1932: The Cestoda of Canadian fishes II. The Hudson Bay drainage system. Contrib. Can. Biol. Fish. (n.s.) 7: 377-403.

WARDLE R.A. 1933: The parasitic helminths of Canadian animals. I. The Cestodaria and Cestoda. Can. J. Res. 8: 317-333.

WARDLE R.A., McLEOD J.A. 1952: The Zoology of Tapeworms. University of Manitoba, Minneapolis, USA, $780 \mathrm{pp}$.

WIERZBICKA J., SOBECKA E. 1985: Parasitic fauna of burbot, Lota lota (L.) in the lake Dabie. Acta Ichthyol. Piscat. 15: 191-202.

ZANDT F. 1924: Fischparasiten des Bodensees. Z. Bakteriol. Parasitenkd. Infekt. 92: 225-271. 